\title{
ANALISIS POTENSI HASIL PENJUALAN TERHADAP KELANCARAN PEMBAYARAN BARANG KONSINYASI PADA TOKO PAKAIAN PD. PASAR TINGKAT LAMONGAN
}

\author{
Sutri Handayani \\ Fakultas Ekonomi, Universitas Islam Lamongan \\ E-mail: sutrihandayni99@gmail.com
}

\begin{abstract}
ABSTRAK
Ketersediaan wilayah pemasaran yang luas dapat mendorong perkembangan usaha, karena dapat meningkatkan penjualan, produksi, jumlah pelanggan, pendapatan, serta laba yang diperoleh. Faktor umum yang paling penting menentukan kelangsungan hidup suatu usaha adalah penjulan. Tujuan penelitian ini adalah untuk mengetahui apakah kualitas barang konsinyasi yang dipasarkan oleh toko pakaian di PD. Pasar Tingkat Lamongan berpengaruh pada hasil penjulan, untuk mengetahui potensi hasil penjualan barang konsinyasi terhadap kelancaran pembayaran barang konsinyasi kepada pihak pemilik barang (consignor).Dari hasil penelitian pada PD. Pasar Tingkat Lamongan untuk tahun 2017, didapatkan kisaran 65\% stan toko yang dioperasikan untuk memasarkan produk pakaian. Dengan demikian seorang pelaku usaha pakaian harus membagi (market share) yang sama dengan pelaku usaha lainnya. Hal ini yang membuat pelaku usaha saling bersaing dalam merebut minat konsumen. Salah satunya melalui penjualan barang konsinyasi. Pelaku usaha toko pakaian pada PD. Pasar tingkat Lamongan mengembangkan usaha melalui penjualan barang konsinyasi yang banyak ditawarkan oleh berbagai pihak pemasok. Namun dalam pelaksanaan penjualan barang konsinyasi ditemukan beberapa masalah yang terakait dengan kualitas barang konsinyasi yang dipasarkan. Masalah tersebut menjadi pengaruh bagi pelaku usaha yakni sulit mengembangkan usahanya secara maksimal. Penelitian ini dilaksanakan dengan tujuan mengetahui apakah kualitas barang konsinyasi yang dipasarkan di toko pakaian PD. Pasar Tingkat Lamongan mempunyai pengaruh pada hasil penjulan dan kelancaran pembayaran barang konsinyasi kepada pihak pemasok barang (consignor).
\end{abstract}

Kata kunci : Hasil Penjualan, Barang Konsinyasi, Kelancaran Pembayaran

\section{PENDAHULUAN}

Seiring perkembangan jaman tingkat persaingan didunia bisnis semakin keras. Setiap pelaku usaha memiliki tujuan untuk mencapai keuntungan yang ditargetkan. Pelaku usaha menggerakkan kegiatan usaha secara maksimal dengan berbagai macam cara agar dapat memberikan kepuasan kepada konsumen sehingga pencapaian tujuan yang diharapkan oleh pelaku usaha dapat terwujud.

$$
\text { Pada masa ekonomi yang }
$$

berkembang saat ini pelaku usaha sering 
kali disulitkan pada masalah pemasaran produk mereka yang disebabkan oleh berbagai macam aspek, diantaranya persaingan dari perusahaan sejenis dan kejenuhan pasar yang menambah kesulitan pelaku usaha yang bersangkutan. Pelaku usaha yang dahulunya adalah pemain tunggal pada suatu wilayah tertentu, kini harus membagi market share yang sama dengan pelaku usaha lainnya. Dengan demikian, pelaku usaha saling bersaing dalam merebut pasar yang sama.

Pelaku usaha dituntut untuk untuk menyeimbangkan usahanya dengan kemajuan yang ada saat ini, terutama dalam hal penjualan. Secara umum, penjualan merupakan kegiatan yang dilakukan oleh pelaku usaha yang mengajak orang lain untuk membeli barang dan jasa yang ditawarkan yang dapat menghasilkan pendapatan bagi pelaku usaha.

Salah satu kebijakan penjualan yang perlu ditentukan oleh pelaku usaha adalah kebijakan mengenai strategi dalam penjualan produk. Penjualan produk dapat dilakukan dengan beberapa cara, antara lain penjualan secara tunai, kredit, cicilan, maupun penjualan secara konsinyasi.
Dengan persaingan yang saat ini terjadi, pelaku usaha menyikapi masalah penjualan tersebut dengan ditempuh salah satunya dengan konsinyasi. Pelaku usaha seringkali keberatan jika harus membeli langsung dari perusahaan. Penyebabnya seperti keterbatasan modal dan resiko besar yang harus ditanggung jika barang yang sudah mereka beli kurang laku dipasaran. Selain itu hal ini juga merupakan strategi perusahaan untuk menjaga keseimbangan jumlah barang yang ada dipasaran, yang tentunya diharapkan supaya pembeli mudah mencari produk mereka dipasaran.

Penjualan konsinyasi adalah pengiriman atau penitipan barang dari pemilik kepada pihak lain yang bertindak sebagai agen penjualan. Hak milik atas barang, tetap masih berada pada pemilik barang sampai barang tersebut terjual. Dalam hubungan dengan penjualan konsinyasi, pihak yang menyerahkan barang disebut pengamanat (consignor), dan pihak yang menerima titipan barang disebut komisioner (consignee). Sistem penjualan konsinyasi dapat dipakai untuk penjualan semua jenis produk. Dari segi pengamanat transaksi jenis 
produk-produk kepada komisioner, biasa disebut barang konsinyasi.

Pada sistem penjualan konsinyasi, pihak pengamanat menetapkan perjanjian mengenai penyerahan hak atas barang dan komisioner bertanggung jawab terhadap barang-barang yang diserahkan sampai barang-barang tersebut terjual kepada pihak ketiga.

Penjualan konsinyasi mempunyai keuntungan-keuntungan tertentu dibandingkan dengan penjualan secara langsung. Salah satu keuntungan penjualan konsinyasi adalah pelaku usaha dapat memperluas daerah atau wilayah pemasaran produknya melaui mitra kerjasama dengan pelaku usaha lainnya. Dengan demikian daerah-daerah yang menjadi tujuan pemasaran perusahaan akan lebih mudah terjangkau. Semakin luas daerah pemasaran, maka semakin terbuka peluang bagi pelaku usaha untuk meningkatkan penawaran atas produknya.

Penjualan yang dilakukan dengan cara konsinyasi akan lebih memudahkan pelaku usaha dalam memasarkan produknya. Hal tersebut dikarenakan dengan melakukan penjualan secara konsinyasi banyak pihak yang akan menjadi mitra perusahaan. Dengan demikian daerah-daerah yang menjadi tujuan pemasaran perusahaan akan lebih mudah terjangkau dan hal ini memungkinkan bagi komisioner untuk meningkatkan jumlah penjualan produk. Secara tidak langsung penjualan konsinyasi mendorong pengembangan usaha, karena peningkatan jumlah penjualan merupakan salah satu pencapaian dalam usaha.

PD. Pasar Tingkat Lamongan yang terdiri dari banyak sekali pelaku usaha didalamnya, yang memanfaatkan peluang yang disediakan, salah satunya dalam pengolahan toko-toko, ini merupakan salah satu unsur penting bagi pelaku usaha dimana menyediakan tempat yang ditujukan sebagai sarana bertemunya penjual dan pembeli. Karakteristik pelaku usaha toko yang sering menjadi hambatan dalam pengelolaan usaha adalah modal, termasuk dalam hal persediaan barang yang dipasarkan. Semakin banyak dan jenis barang yang ditawarkan oleh pelaku usaha toko semakin tinggi modal yang dikeluarkan oleh penjual, serta semakin tinggi pula tingkat minat konsumen pada barang yang dijual tersebut.

Persediaan barang yang dipasarkan di toko-toko pakain PD. Pasar Tingkat 
Lamongan tercatat hampir $50 \%$ adalah barang konsinyasi dari para pemasok (pengamanat) mayoritas daerah Jawa Tengah. Perbandingan ini sejajar dengan barang yang dibeli oleh pemilik toko pakaian secara tunai di Surabaya. Bagi pengamanat melalui penjualan konsinyasi tersebut dapat memperluas daerah pemasaran produk pakaiannya tanpa harus mengeluarkan biaya yang besar, dengan cukup megambil sedikit keuntungan yang diperoleh demi kelancaran produk yang dijual. Dengan demikian, pemilik usaha pakain memperoleh kesempatan untuk mengembangkan usaha melalui ketersediaan barang konsinyasi tersebut.

Hasil pra riset yang telah dilakukan penulis menemukan bahwa barang konsinyasi rata-rata dipasarkan di toko-toko pakaian PD. Pasar Tingkat Lamongan mempunyai kualitas dibawah dari kualitas barang yang dibeli tunai oleh penjual di Surabaya. Namun hal tersebut tidak membuat lemahnya penjual untuk memasarkan barang konsinyasi. Faktor tersebut ditunjang dengan harga yang lebih murah dibanding dengan harga standar produk tersebut dan pembayaran hasil penjualan produk konsinyasi bisa diansur (cicilan). Pembayaran barang konsinyasi secara angsuran ini yang menjadi unsur utama tingkat ketertarikan penjual pakaian di PD. Pasar Tingkat Lamongan untuk memasarkan produk barang konsinyasi.

$$
\text { Berdasarkan latar belakang }
$$
tersebut diatas maka dapat dirumuskan masalah sebagai berikut: Apakah kualitas barang konsinyasi pada toko pakaian di PD. Pasar Tingkat Lamongan berpengaruh pada hasil penjulan, Bagaimana potensi hasil penjualan barang konsinyasi terhadap kelancaran pembayaran barang konsinyasi kepada pihak pemilik barang (consignor).

Tujuan penelitian ini adalah untuk mengetahui apakah kualitas barang konsinyasi yang dipasarkan oleh toko pakaian di PD. Pasar Tingkat Lamongan berpengaruh pada hasil penjulan, untuk mengetahui potensi hasil penjualan barang konsinyasi terhadap kelancaran pembayaran barang konsinyasi kepada pihak pemilik barang (consignor).

\section{TINJAUAN PUSTAKA}

Menurut Wikipedia Indonesia penjualan (sales) adalah aktivitas atau bisnis menjual produk atau jasa. Dalam proses penjualan, penjual atau penyedia barang dan jasa memberikan kepemilikan suatu komoditas kepada pembeli untuk suatu harga tertentu. 
Setelah kepemilikan berada ditangan konsumen penjual mendapatkan sesuatu yang diterima disebut hasil penjualan.

Menurut Perda Kabupaten Lamongan No.6 Tahun 2008 tentang Perusahaan Daerah Pasar Kabupaten Lamongan, Bahwa dalam rangka memaksimalkan potensi dan fungsi pasar, sehingga dapat meningkatkan pertumbuhan ekonomi masyarakat dan Pendapatan Asli Daerah. Maka diperlukan lembaga dengan pola manajemen yang tepat dan professional yang dapat memberikan fasilitas perpasaran dan mampu mencukupi konsumsi masyarakat terhadap barangbarang kebutuhan rumah tangga maupun barang dagangan lainnya. Salah satunya melalui Pasar Tingkat yang banyak dimanfaatkan oleh pelaku usaha.

Dalam Kamus Besar Bahasa Indonesia, istilah konsinyasi diartikan sebagai kegiatan penitipan barang dagangan kepada agen atau orang untuk dijualkan dengan pembayaran kemudian (jual titip).

Maria Simamora (2005) penjualan konsinyasi melibatkan dua pihak yaitu pihak yang memiliki barang disebut Pengamanat (consignor) dan pihak yang mengusahakan penjualan barang disebut Komisioner (consignee). Penjualan konsinyasi dalam pengertian sehari-hari dikenal dengan sebutan penjualan dengan cara titipan. Sebelum pengamanat dan komisioner melakukan kegiatanya mereka menyusun suatu kontrak perjanjian atau persetujuan. Ketentuan-ketentuan dalam penjulan konsinyasi pada umumnya dinyatakan secara tertulis dan menekankan sifat hubungan kerjasama antara kedua bela pihak.

Menurut Yendrawati (2008) Konsinyasi adalah penjualan dengan cara pemilik menitipkan barang kepada pihak lain untuk dijualkan dengan harga dan syarat yang telah diatur dalam perjanjian. Dalam penjualan konsinyasi ada dua pihak yaitu pihak yang menitipkan barang dan pihak yang dititipi barang. Perjanjian kedua belah pihak tersebut disebut perjanjian konsinyasi. Perjanjian konsinyasi berisi mengenai hak dan kejawiban kedua belah pihak. Oleh karena itu maka akuntansi juga diselenggarakan oleh pengamanat dan juga diselenggarakan oleh komisioner.

Menurut Utoyo Widaya (1991) Keuntungan Penjualan Konsinyasi bagi Pengamanat (Consignor) adalah :

1. Untuk memperluas daerah pemasaran suatu produk oleh pengamanat 
(consignor) yang disebabkan oleh beberapa hal, antara lain; memperkenalkan produk baru, dimana masyarakat belum mengetahui produk tersebut, dan untuk membuka devisi penjualan di suatu daerah adalah sangat mahal investasinya.

2. Pengamanat dapat mengendalikan (mengontrol) harga jual dari agen (penerima barang konsinyasi). Hal ini dimungkinkan karena agen hanya menjual dengan harga yang telah ditetapkan oleh pengamanat dan agen hanya menerima komisi atas penjualan tersebut, tanpa mengambil keuntungan dari harga jual barang konsinyasi.

3. Barang konsinyasi tidak ikut disita apabila terjadi kebangkrutan pada pihak komisioner sehingga resiko kerugian dapat ditekan.

4. Pengamanat dapat memperoleh spesialis penjualan, terutama untuk penjualan gandum, ternak, dan hasil bumi. Imbalan untuk jasa seperti ini seringkali berupa komisi, yang dapat berupa persentase harga jual atau dapat juga berupa jumlah yang tetap untuk setiap unit batang yang terjual.

Sedangkan Keuntungan yang diperoleh Komisioner (Consignee) melalui penjualan konsinyasi, antara adalah :

1. Komisioner tidak dibebani resiko menanggung rugi bila gagal dalam penjualan barang- barang konsinyasi.

2. Komisioner tidak mengeluarkan biaya operasi penjualan konsinyasi karena semua biaya akan diganti atau ditanggung oleh pengamanat.

3. Apabila terdapat barang konsinyasi yang rusak dan terjadi fluktuasi harga, maka hal tersebut bukan tanggungan komisioner.

4. Kebutuhan modal kerja dapat dikurangi, sebab komisioner hanya berfungsi sebagai penerima dan penjual barang konsinyasi untuk pengamanat.

5. Komisioner berhak mendapatkan komisi dari hasil penjualan konsinyasi.

\section{METODE PENELITIAN}

Untuk mendapatkan data yang diperlukan, penulis melakukan penelitian pada toko-toko pakaian di PD. Pasar Tingkat Lamongan yang memanfaatkan barang konsinyasi sebagai salah satu unsur yang mereka pasarkan, dimana objek penelitian yang di teliti adalah potensi hasil penjualan. 
Dalam penelitian ini, data yang diperoleh adalah data primer, dimana data ini memerlukan pengolahan lebih lanjut, diperoleh melalui angket yang disebarkan dan data yang diperoleh melalui wawancara. Selanjutnya teknik pengumpulan data menggunakan teknik Observasi dan Wawancara. Teknik Observasi, yaitu dengan cara melakukan pengamatan langsung ke toko-toko di PD. Pasar Tingkat Lamongan, dan melakukan wawancara, dengan melakukan tanya jawab dan diskusi secara langsung dengan pihak pengelola toko pakaian, khususnya toko yang menjual barang konsinyasi serta melakukan wawancara kepada pemasok barang konsinyasi.

Analisa data yang penulis gunakan dalam penelitian ini adalah analisis menggunakan Metode deskriftif yaitu suatu metode dalam meneliti status sekelompok manusia, suatu objek, suatu set kondisi, suatu system pemikiran, ataupun suatu kelas peristiwa pada masa sekarang. Data yang diperoleh, disusun, dianalisis, sehingga dapat memberikan informasi yang jelas.
Tahap Penelitian dibagi menjadi 5 yaitu :
A. Observasi di area lokasi
B. Pengumpulan data primer
C. Wawancara
D. Analisis kajian
E. Laporan akhir hasil kajian

\section{PEMBAHASAN}

Untuk PD. Pasar Tingkat Lamongan, untuk tahun 2017, terdapat kisaran $65 \%$ stan toko yang dioperasikan untuk memasarkan produk pakaian. Objek penelitian yang dilakukan penulis berfokus pada potensi hasil penjualan. Dimana berfokus pada kualitas barang konsinyasi terhadap hasil penjualan dan kelancaran pembayaran barang konsinyasi.

Dari sampel yang sudah penulis kumpulkan melalui pengamatan dan wawancara pada 20 toko pakaian yang memasarkan produk barang konsinyasi dapat dipaparkan dalam Tabel Prosentase Peran Pemasaran Barang Konsinyasi oleh toko pakain di PD. Pasar Tingkat Lamongan.

Tabel 1. Prosentase Peran Pemasaran Barang Konsinyasi

\begin{tabular}{|c|c|c|}
\hline Jumlah toko & Barang konsinyasi yang dijual & Kriteria \\
\hline 2 & $60 \%$ & Mempunyai peran relatif seimbang \\
\hline 4 & $50 \%$ & Mempumyai peran seimbang \\
\hline
\end{tabular}




\begin{tabular}{|c|c|c|}
\hline Jumlah toko & Barang konsinyasi yang dijual & Kriteria \\
\hline 6 & $30 \%$ & Cukup mempunyai peran \\
\hline 8 & $25 \%$ & Cukup mempunyai peran \\
\hline
\end{tabular}

Menyikapi kualitas barang konsinyasi yang dipasarkan pada 20toko pakaian di PD. Pasar Tingkat Lamongan terhadap hasil penjualannya dipaparkan pada Tabel Prosentase Hasil Penjualan Barang Konsinyasi dan Barang Tunai.

Tabel 2. Prosentase Hasil Penjualan

\begin{tabular}{|c|c|c|c|c|}
\hline \multirow{2}{*}{$\begin{array}{c}\text { Jum- } \\
\text { lah } \\
\text { toko }\end{array}$} & \multicolumn{2}{|c|}{$\begin{array}{c}\text { Barang } \\
\text { Konsinyasi }\end{array}$} & \multicolumn{2}{|c|}{ Barang Tunai } \\
\hline & $\begin{array}{l}\text { Perse } \\
\text { diaan }\end{array}$ & $\begin{array}{c}\text { Hasil } \\
\text { Penjua } \\
\text { lan }\end{array}$ & $\begin{array}{l}\text { Perse } \\
\text { diaan }\end{array}$ & $\begin{array}{c}\text { Hasil } \\
\text { Penjua } \\
\text { lan }\end{array}$ \\
\hline 2 & $60 \%$ & $55 \%$ & $40 \%$ & $30 \%$ \\
\hline 4 & $50 \%$ & $40 \%$ & $50 \%$ & $45 \%$ \\
\hline 6 & $30 \%$ & $20 \%$ & $70 \%$ & $65 \%$ \\
\hline 8 & $25 \%$ & $20 \%$ & $75 \%$ & $65 \%$ \\
\hline
\end{tabular}

Prosentase peran dan hasil penjualan barang konsinyasi, mempunyai keadaan setara dengan barang yang dibeli penjual secara tunai, meskipun kulialitas barang konsinyasi berbeda, hal ini terjadi terkait dengan harga barang konsinyasi tersebut yang murah, sehingga minat konsumen juga setara dan bagi penjual sangat diuntungkan sebab pembayaran barang konsinyasi melaui angsuran.

$$
\text { Barang konsinyasi yang }
$$
diserahkan kepada penjual tentu disertai dengan perjanjian yang menyangkut besarnya pembayaran dan jangka waktu pembayaran angsuran. Pembayaran angsuran barang konsinyasi oleh toko pakaian di PD. Pasar Tingkat Lamongan ini berbeda dengan pembayaran angsuran pada umumnya, barang konsinyasi yang terjual tidak disertai bunga, melainkan hanya mengangsur harga pokok barang konsinyasi tersebut.

Dengan potensi hasil penjualan yang sudah dipaparkan pada tabel diatas, dapat diperkirakan kelancaran pembayaran barang konsinyasi adalah baik, artinya sesuai dengan harapan. Dengan demikian untuk memastikan asumsi tersebut penulis juga mengambil sampel dengan melakukan wawancara kepada pemasok yang penulis gambarkan dalam grafik,

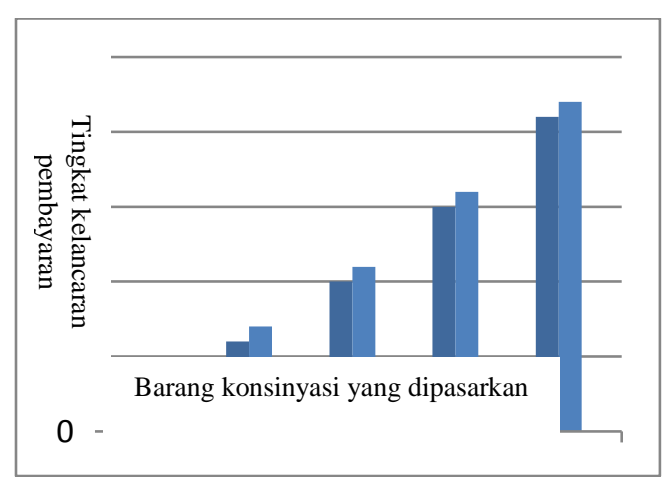

Gambar 1. Grafik Kelancaran Pembayaran Barang Konsinyasi 


\section{KESIMPULAN DAN SARAN}

\subsection{KESIMPULAN}

Berdasarkan hasil penelitian dan pembahasan maka dapat dinyatakan, kualitas barang konsinyasi yang dipasarkan pada toko pakaian di PD. Pasar Tingkat Lamongan tidak berpengaruh pada hasil penjualan meskipun mempunyai kualitas yang berbeda dengan barang tunai. Hal ini dikarenakan harga barang konsinyasi yang ditawarkan lebih murah. Ketertarikan penjual pakaian di PD. Pasar Tingkat Lamongan menjual barang konsinyasi tersebut dikarenakan antara lain kebutuhan akan modal kerja dapat dikurangi, minimnya resiko dan utamanya adalah pembayaran barang konsinyasi bisa diansur (cicilan).

Potensi hasil penjulan barang konsinyasi meningkat jika penjual memasarkan barang konsinyasi dengan tingkat volume yang tinggi, dan dengan peningkatan penjualan barang konsinyasi tersebut berpengaruh baik pada kelancaran pembayaran barang konsinyasi.

\subsection{SARAN}

Berdasarkan kesimpulan diatas maka saran-saran yang dapat penulis sampaikan adalah diharapkan pengelola toko pakaian di PD. Pasar Tingkat Lamongan sebagai pelaku usaha untuk memaksimalkan usaha yang dikelolanya, salah satu cara dengan meningkatkan persediaan barang yang dipasarkannya. Faktor tersebut bisa dijalankan dengan menoperasikan atau memasarkan barang konsinyasi yang saat ini banyak ditawarkan oleh pemasok (consignor).

\section{DAFTAR PUSTAKA}

Simamora, Maria. 2005. Analisis Penerapan Akuntansi Konsinyasi. Skripsi . USU.

Widayat, Utoyo. 1991 . Akuntansi Keuangan Lanjutan: Ikhtisar Teori dan Soal, Ed. Revisi. Jakarta : LPFE UI.

Yendrawati, Reni. 2008. Akuntansi Keuangan lanjutan 1. Yogyakarta : EKONISIA.

Lamongankab . 2017. Tentang ubah Perda no 6 tahun 2008 tentang PD. Pasar http://lamongankab.go.id/baghukum/files/2017/08/No-11-ttgubah-perda-no-6-tahun-2008-ttgPD-Pasar.pdf . Diakses pada 12 November 2017

Uzi . 2016 . Penjualan Konsinyasi Akuntansi

http://uzi15.blogspot.co.id/2016/02 /penjualan-konsinyasi- 
akuntansi.html?m=1 .Diakses pada 12 November 2017
Wikipedia. Penjualan https://id.m.wikipedia.org/wiki/Pe njualan . Diakses pada 12 November 2017 